\title{
REVISION OF THE MCSAP ALLOCATION FORMULA: SUMMARY REPORT
}

\author{
Lorena F. Truett \\ Stacy C. Davis \\ Patricia S. Hu
}

September 2000

\author{
Prepared for the \\ Federal Motor Carrier Safety Administration \\ U.S. DEPARTMENT OF TRANSPORTATION \\ Washington, D.C. 20590 \\ Prepared by the \\ Center for Transportation Analysis \\ OAK RIDGE NATIONAL LABORATORY \\ Oak Ridge, Tennessee 37831-6073 \\ managed by \\ UT-BATTELLE, LLC \\ for the \\ U.S. DEPARTMENT OF ENERGY \\ under Contract No. DE-AC05-00OR22725
}




\section{CONTENTS}

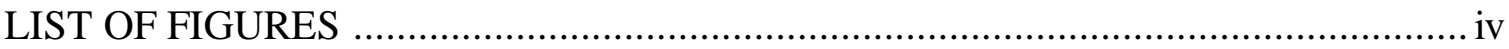

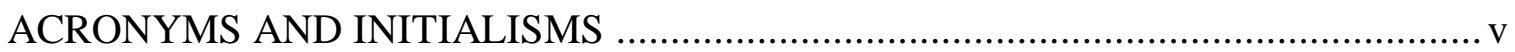

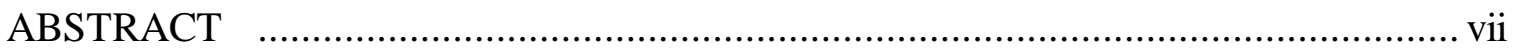

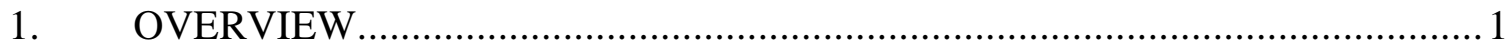

1.1 MCSAP Background and Brief History .....................................................

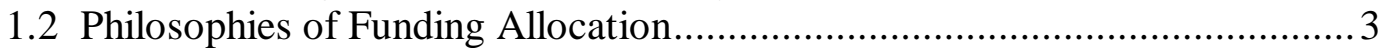

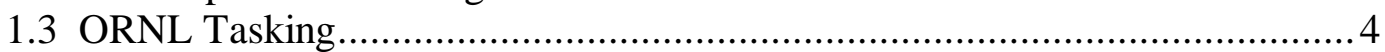

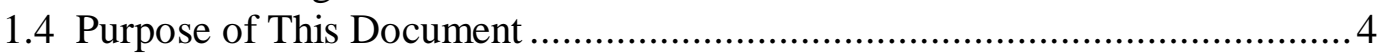

2. SUMMARY OF WORKGROUP MEETINGS ……................................... 4

2.1 Workgroup Meeting, June 24-26, 1997, Arlington, Virginia...........................5

2.2 Workgroup Meeting, February 3-5, 1998, Oak Ridge, Tennessee ..................5

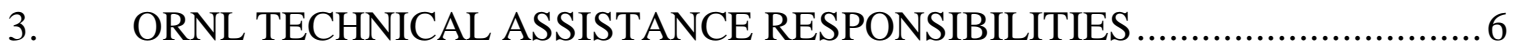

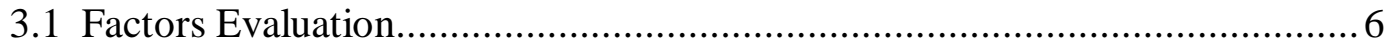

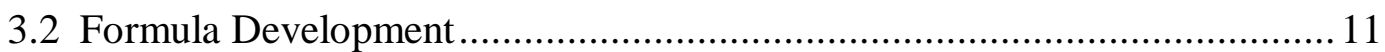

3.3 Scenario Comparisons ............................................................................ 12

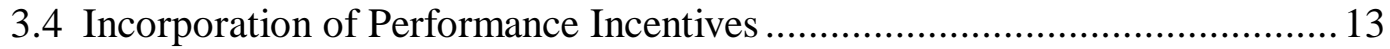

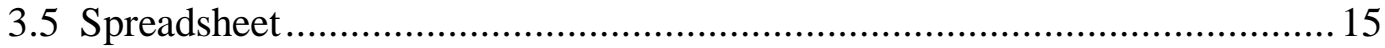

4. FEDERAL REGISTER (49 CFR PART 350) NOTICES ....................................15

4.1 Notice of Proposed Rule Making (March 1999) ........................................... 15

4.2 Final Rule (March 2000) ....................................................................... 15

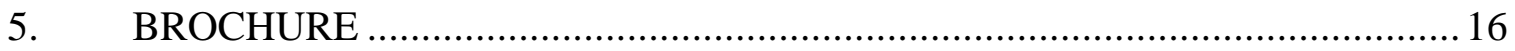

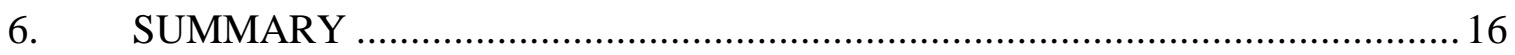

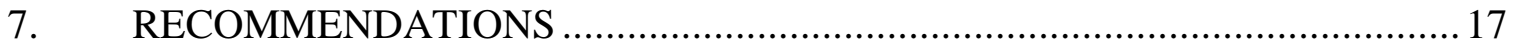

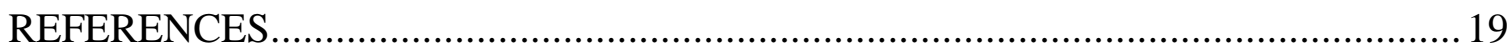

APPENDIX A: MCSAP FORMULA WORKGROUP PARTICIPANTS …………..... A-1

APPENDIX B: FACTORS OVERVIEW …………..........................................

APPENDIX C: EXAMPLE OF SCENARIO ANALYSIS ……................................

APPENDIX D: CRASH-RELATED DATA FOR POTENTIAL USE

AS PERFORMANCE-BASED FACTORS ……………………....

APPENDIX E: SPREADSHEET ……………………………………….... E-1

APPENDIX F: MOST COMMON COMMENTS ON THE NOTICE

OF PROPOSED RULEMAKING (NPRM) ....................................F-1 


\section{LIST OF FIGURES}

$1 \quad$ Change index of road miles, by State, for the years $1992-1997$....................... 7

2 Change index of truck registrations, by State, for the years $1992-1997 \ldots \ldots \ldots \ldots \ldots . . .8$

3 Desirable features of a factor being considered for use in the MCSAP formula .... 9

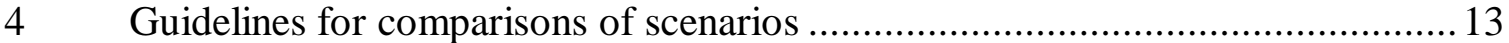




\section{ACRONYMS AND INITIALISMS}

$\begin{array}{ll}\text { AVMT } & \text { All Vehicle Miles Traveled } \\ \text { CDL } & \text { Commercial Driver's License } \\ \text { CDLIS } & \text { Commercial Driver's License Information System } \\ \text { CMV } & \text { Commercial Motor Vehicle } \\ \text { CVMT } & \text { Commercial Vehicle Miles Traveled } \\ \text { FARS } & \text { Fatality Analysis Reporting System } \\ \text { FHMR } & \text { Federal Hazardous Materials Regulation } \\ \text { FHWA } & \text { Federal Highway Administration } \\ \text { FMCSA } & \text { Federal Motor Carrier Safety Administration } \\ \text { FY } & \text { Fiscal Year } \\ \text { IFTA } & \text { International Fuel Tax Agreement } \\ \text { IRP } & \text { International Registration Plan } \\ \text { ISTEA } & \text { Intermodal Surface Transportation Efficiency Act } \\ \text { ITS } & \text { Intelligent Transportation System } \\ \text { LPG } & \text { Liquid Propane Gas } \\ \text { MCMIS } & \text { Motor Carrier Management Information System } \\ \text { MCSAP } & \text { Motor Carrier Safety Assistance Program } \\ \text { MUCC } & \text { Minimum Uniform Crash Criteria } \\ \text { NGA } & \text { National Governor's Association } \\ \text { OOS } & \text { Out of Service } \\ \text { NHS } & \text { National Highway System } \\ \text { NPRM } & \text { Notice of Proposed Rulemaking } \\ \text { ORNL } & \text { Oak Ridge National Laboratory } \\ \text { TEA-21 } & \text { Transportation Equity Act for the 21 }{ }^{\text {st }} \text { Century } \\ \text { TIUS } & \text { Truck Inventory and Use Survey } \\ \text { VMT } & \text { Vehicle Miles Traveled } \\ & \end{array}$




\begin{abstract}
In 1982, Congress authorized the Motor Carrier Safety Assistance Program (MCSAP), a Federal grant-in-aid program to improve commercial motor carrier safety. MCSAP was reauthorized in 1986, 1991, and 1998. In June 1997, in anticipation of and preparation for reauthorization, a MCSAP Formula Workgroup convened to analyze requirements for a new allocation formula and to develop the formula. Because of provisions in the Transportation Equity Act for the 21st Century (TEA-21), a major change in approach was to consider including performance (i.e., safety improvements) in the formula.

Oak Ridge National Laboratory (ORNL) actively participated in the Workgroup activities, provided technical assistance in evaluating factors and conducting scenario analyses, prepared regulatory language for the Federal Register Notice of Proposed Rulemaking (NPRM), analyzed NPRM comments and recommended responses to the comments, assisted with preparation of the Federal Register Final Rule, developed the final spreadsheet, and prepared an informational brochure on MCSAP for use by the States. The allocation of MCSAP funds for FY2001 will use the new formula.
\end{abstract}




\section{REVISION OF THE MCSAP ALLOCATION FORMULA: SUMMARY REPORT}

In 1997, researchers from Oak Ridge National Laboratory (ORNL) teamed with staff members from the U.S. Department of Transportation, Federal Highway Administration (FHWA) Headquarters and with Federal representatives from each of the nine FHWA regions to form a Workgroup. The mission of this Workgroup was to examine and, if necessary, revise the formula that apportioned funds to the States and Territories ${ }^{1}$ for improving highway safety with regard to motor carriers.

\section{OVERVIEW}

A commercial motor vehicle (CMV) is defined as a vehicle used on public highways in commerce with any one of the following characteristics:

- a gross vehicle weight, gross vehicle weight rating, gross combination weight, or gross combination weight rating of 4,537 $\mathrm{kg}(10,000 \mathrm{lbs})$ or more,

- regardless of weight, the capacity to transport eight or more passengers, including driver, or

- regardless of weight, an intended purpose to transport hazardous materials, with a requirement to be placarded under the Federal Hazardous Materials Regulations (FHMRs).

The Motor Carrier Safety Assistance Program (MCSAP) is a Federal grant program to the States with an objective to reduce the number and severity of accidents and hazardous materials incidents involving commercial motor vehicles. States use these grant funds to develop and implement programs designed to promote safety by enforcing Federal and State laws and regulations pertaining to commercial vehicle safety. National program elements include five activities:

- driver/vehicle inspections,

- traffic enforcement,

- compliance reviews,

- public education and awareness, and

- data collection.

\footnotetext{
${ }^{1}$ Territories eligible to apply for MCSAP funds include Puerto Rico, American Samoa, the Virgin Islands, Guam, and the Commonwealth of the Northern Marianas. Hereinafter, in this report, the term "State" also includes the Territories.
} 


\subsection{MCSAP Background and Brief History}

MCSAP was first authorized in 1982 in the Surface Transportation Assistance Act and was subsequently re-authorized in the Commercial Motor Vehicle Safety Act of 1986, the Intermodal Surface Transportation Efficiency Act (ISTEA) of 1991, and the Transportation Equity Act for the $21^{\text {st }}$ Century (TEA-21) in 1998. Previously administered through the FHWA, MCSAP authority was delegated to the newly created Federal Motor Carrier Safety Administration (FMCSA) in January 2000.

\section{MCSAP under ISTEA}

Under ISTEA, MCSAP annual funds grew from $\$ 65$ million in FY1991 to $\$ 90$ million in FY1997. After an administrative takedown of up to $1.25 \%$ of its total funding, the MCSAP program under ISTEA distributed funding through three separate grants - basic funds, supplemental funds, and special funds. Supplemental grants were awarded to States that had already qualified for a basic grant to fund additional activities or innovative programs.

Special grants were awarded to States to (1) help meet conditions to receive a basic grant or (2) develop expanded activities if the State already met requirements to participate in the basic program. Basic program funds were distributed to the States via a formula consisting of five equally weighted factors:

- road miles (all highways),

- vehicle miles traveled (VMT) for all vehicles (i.e., not only commercial vehicles),

- number of commercial vehicles over 10,000 pounds gross vehicle weight rating based on vehicle registrations,

- population (most current decennial census), and

- $\quad$ special fuel consumption (net after reciprocity adjustment).

The ISTEA legislation required FHWA to review the allocation formula and update the data used for each factor. Therefore, in 1993, FHWA's Office of Motor Carriers examined several potential new factors (e.g., lane miles and land area). After examination of the possible impact of new factors, FHWA concluded that there was no compelling reason to change the formula. To receive MCSAP funds under ISTEA, States were required to submit State safety planning documents, provide a $20 \%$ matching share, and conform to certain other requirements as documented in the Federal Register, Vol. 57, No. 174, September 8, 1992, pp. 40946-40964.

\section{MCSAP under TEA-21}

Under TEA-21, which was signed into law on June 9, 1998, MCSAP funds were authorized at \$79 million for FY1998, \$90 million in FY1999, \$95 million in FY2000, \$100 million in 
FY2001, \$105 million in FY2002, and \$110 million in FY2003. ${ }^{2}$ Beginning in FY2001, an additional \$55 million will be available each year for MCSAP from the Motor Carrier Safety Improvement Act of $1999 .^{3}$

A key component of TEA-21 legislation was the emphasis on implementing State-based commercial vehicle programs that show positive results, that is, performance improvements. Therefore, distribution of program funds under TEA-21 was different from the grant programs of ISTEA. After deducting funding for administrative expenses (up to $1.25 \%$ ), high priority activities (5\%), and border activities (5\%), the remaining MCSAP funds were authorized to be split between basic program funds and incentive (i.e., performance-based) funds. (No incentive funds were distributed in FY2000.) Funds for high priority activities were provided to States and local agencies to support national priorities for CMV safety and compliance. Funds for border activities were provided to States and local agencies to support safety and enforcement along the U.S. border. The split between basic and incentive funds is explained in greater detail in Section 3.4.

In June 1997, in preparation for reauthorization, the Office of Motor Carriers (at that time part of the FHWA) convened a MCSAP Workgroup to review the allocation formula, analyze potential factors for a new formula, and devise strategies for incorporating performance features within the allocation process. The Workgroup contained representatives from Headquarters, Federal representatives of each of the nine FHWA regional offices, and the technical assistance team from ORNL.

\subsection{Philosophies of Funding Allocation}

When attempting to devise a fair and reasonable method for allocating funds, it is important to be aware of several issues. First, States differ in land area, population, highway features, traffic density, and safety issues. Motor carrier safety problems in remote South Dakota could be very different from those in metropolitan New Jersey.

States use MCSAP funds to promote safety through enforcement, training, new initiatives, hiring of program personnel, and other MCSAP-approved applications. It is, therefore, assumed that a State will benefit most if consistent year-to-year funding can be expected, which implies that programming can be planned for and included in the State's budget process. In the TEA-21 legislation, States were instructed to examine prior accident records and to seek innovative strategies to correct their motor carrier safety problems. Performance improvement was encouraged.

\footnotetext{
${ }^{2}$ U.S. Department of Transportation, Federal Motor Carrier Safety Administration. "Motor Carrier Safety Assistance Program (MCSAP)," Docket No. FHWA-98-4878, Notice of Proposed Rulemaking (NPRM); Request for Comments, Fed. Regist., Vol. 64, No. 45, Tuesday, March 9, 1999, p. 11415.

${ }^{3}$ U.S. Department of Transportation, Federal Motor Carrier Safety Administration. "Motor Carrier Safety Assistance Program,” Docket No. FMCSA-98-4878, Final Rule, Fed. Regist., Vol. 65, No. 55, Tuesday, March 21, 2000, p. 15095.
} 
A major problem facing the MCSAP Workgroup was to determine how to allocate funds to promote performance improvement. If a certain percentage of MCSAP funds were to be set aside for performance improvement, should these funds be allocated to States with the worst motor carrier crash records in order to fund additional safety programs (i.e., "put the money where the problem is")? Or should funds be allocated to States that actually improve their safety records as a reward for accomplishing the safety objective?

\subsection{ORNL Tasking}

At the time that the MCSAP Workgroup was organized, ORNL received funding to assist with the reallocation process. Specifically, ORNL was asked to complete the following tasks:

- actively participate in and facilitate Workgroup activities to review and revise the formula,

- identify and evaluate potential formula factors,

- provide technical assistance with formula development, and conduct scenario analyses to evaluate the impacts of various permutations of factors and formulas on States and regions,

- automate the Lotus 123 spreadsheet to calculate the distribution of funds,

- $\quad$ prepare regulatory language for the Federal Register Notice of Proposed Rulemaking (NPRM),

- analyze comments received on the NPRM,

- assist with preparation of the Federal Register Final Rule, and

- produce an informational brochure on MCSAP for use by the States.

After completion of these tasks, ORNL prepared this summary report to document the activities involved in formula development.

\subsection{Purpose of This Document}

This report documents the activities of the MCSAP Workgroup and the processes for getting final approval for a revised allocation formula for the MCSAP. Particular emphasis is placed on the involvement of ORNL. The purpose of the report is to provide guidance during the next formula evaluation process.

\section{SUMMARY OF WORKGROUP MEETINGS}

In 1997, in order to reevaluate the MCSAP allocation formula, the FHWA convened a MCSAP Formula Workgroup, which included Federal representatives from each of the nine Regions and FHWA Headquarters, plus a team from ORNL to facilitate discussion and assist with the analyses. (See Appendix A for a listing of Workgroup participants.) Two Workgroup meetings were held, one in Arlington, Virginia, and one in Oak Ridge, 
Tennessee. In addition, Workgroup participants communicated via phone calls, email, and one conference call involving all members. The Workgroup's objectives were as follows:

C to review the current formula and its factors in a historical context of fairness, equity, and safety impact,

C to understand the needs of each of the regions and their individual States and Territories and to provide an analytic approach to the reexamination of the formula,

C to consider potential new factors and to evaluate their impact on recipients of MCSAP funds, and

C to discuss options for apportioning funds based on safety performance.

The primary objective of MCSAP is to promote safety. With safety improvements as the overriding consideration, the Workgroup worked to develop a fair and equitable allocation formula that, to the extent possible, ensured relative continuity in funding distribution and had as little negative impact as possible on any State or Territory. The charge to the Workgroup was to advance a sound, national program that served to promote commercial vehicle safety.

\subsection{Workgroup Meeting, June 24-26, 1997, Arlington, Virginia}

At this meeting, the Workgroup received orientation on formula development and sources of potential factors. Presentations on the existing MCSAP factors and data sources were given, and definitions of terms such as "floor," "ceiling," and "hold harmless" were shared. ORNL presented a brief analysis of various potential data sources. This analysis considered data quality (e.g., simplicity, stability, reliability, predictability, and availability), frequency of collection, and usefulness of the data. Workgroup participants from the nine FHWA regions discussed regional and State issues. The TEA-21 initiative on improving safety performance was emphasized; however, the group was not charged with incorporating performance improvement within the formula. At the end of the meeting, an action plan for conducting several more scenarios and examining several additional data sources for potential factors was developed. Lists of the data sources that were examined, as well as the results of the factors analyses, are given in Section 3.1.

\subsection{Workgroup Meeting, February 3-5, 1998, Oak Ridge, Tennessee}

At this meeting, the Workgroup arrived at a consensus on the factors (road miles, vehicle miles traveled, special fuels, and annual population estimates) to be used in the formula for allocating basic program funds. The preferred formula weighted the four factors equally. The group also recommended "floor" and "ceiling" limits and the addition of a "hold harmless to 1996" condition (see also Section 3.2).

After a recommendation for the factors and formula had been determined, the Workgroup tackled the problem of determining a philosophy for allocation based on performance (see also Section 3.4). The Workgroup decided that the performance-based funds should be used to reward exemplary and improved performance. Various ways of measuring performance 
improvement were discussed, including improvements in timeliness/accuracy of data uploads from the States to Federal motor carrier data bases, reduction in the number of crashes/fatalities involving large trucks, reduction in rates of crashes/fatalities involving large trucks, use of innovative programs, and improvements in State planning.

Several proposals for distributing the incentive grants were discussed. The Workgroup did not arrive at a final consensus on a plan for allocation of performance-based funding. For more information on the incentive funding, see Section 3.4.

\section{ORNL TECHNICAL ASSISTANCE RESPONSIBILITIES}

ORNL provided technical assistance to the Workgroup by identifying and evaluating potential data sources for possible use as factors in the formula, by analyzing the pros and cons of each data source, and by developing the Lotus 123 programs and spreadsheets to test impacts of different formulas and scenarios.

\subsection{Factors Evaluation}

ORNL provided an analysis of the five factors (road mileage, VMT, commercial vehicle registrations, population, and special fuel consumption) that were in the formula as it existed in June 1997. Four of the factors - road mileage, VMT, population, and special fuel consumption - were considered valid because they provided a measure of overall traffic volume, indicated the potential for crashes, were related to motor carrier activity levels, were easy to understand, and were from reliable sources. The special fuels factor was considered especially valuable as a measure of motor carrier activity because it is based on actual diesel and liquid propane gas (LPG) fuel usage within a State and is from an audited program for all States. ${ }^{4}$

The Workgroup decided that annual population estimates were preferred over the decennial census because they more accurately represented population sizes at a particular point in time. In addition, the gradual changes in population over the years would not cause extreme impacts on funding allocations to the States as could potentially occur with population changes between one decennial census and the next.

The Workgroup agreed that the use of registration data was not a good measure of commercial truck activity, because trucks could be registered in one State but operate primarily in another State. The Workgroup also realized, based on ORNL's analysis, that the quality of the registration data was questionable, since data values fluctuated widely year by year. Figures 1 and 2 show graphically the stability indexes for road miles, which is a stable factor, and registrations, which is not a stable factor.

\footnotetext{
${ }^{4}$ This program is administered by FHWA's Office of Highway Policy Information.
} 

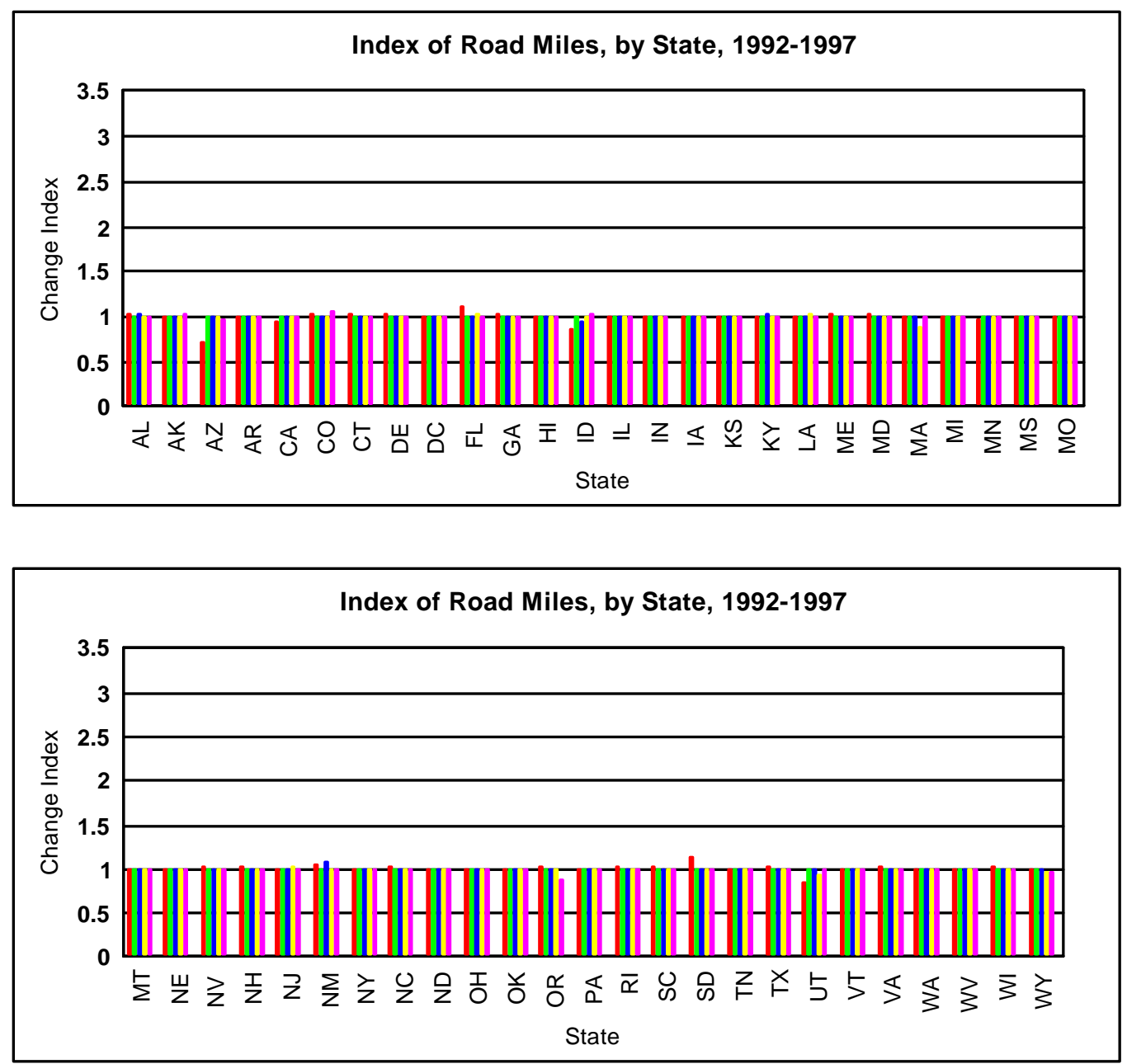

Figure 1. Change index of road miles, by State, for the years 1992-1997. The change index, which is computed by dividing the current year's value by the previous year's value, shows the stable nature of the road miles factor. 

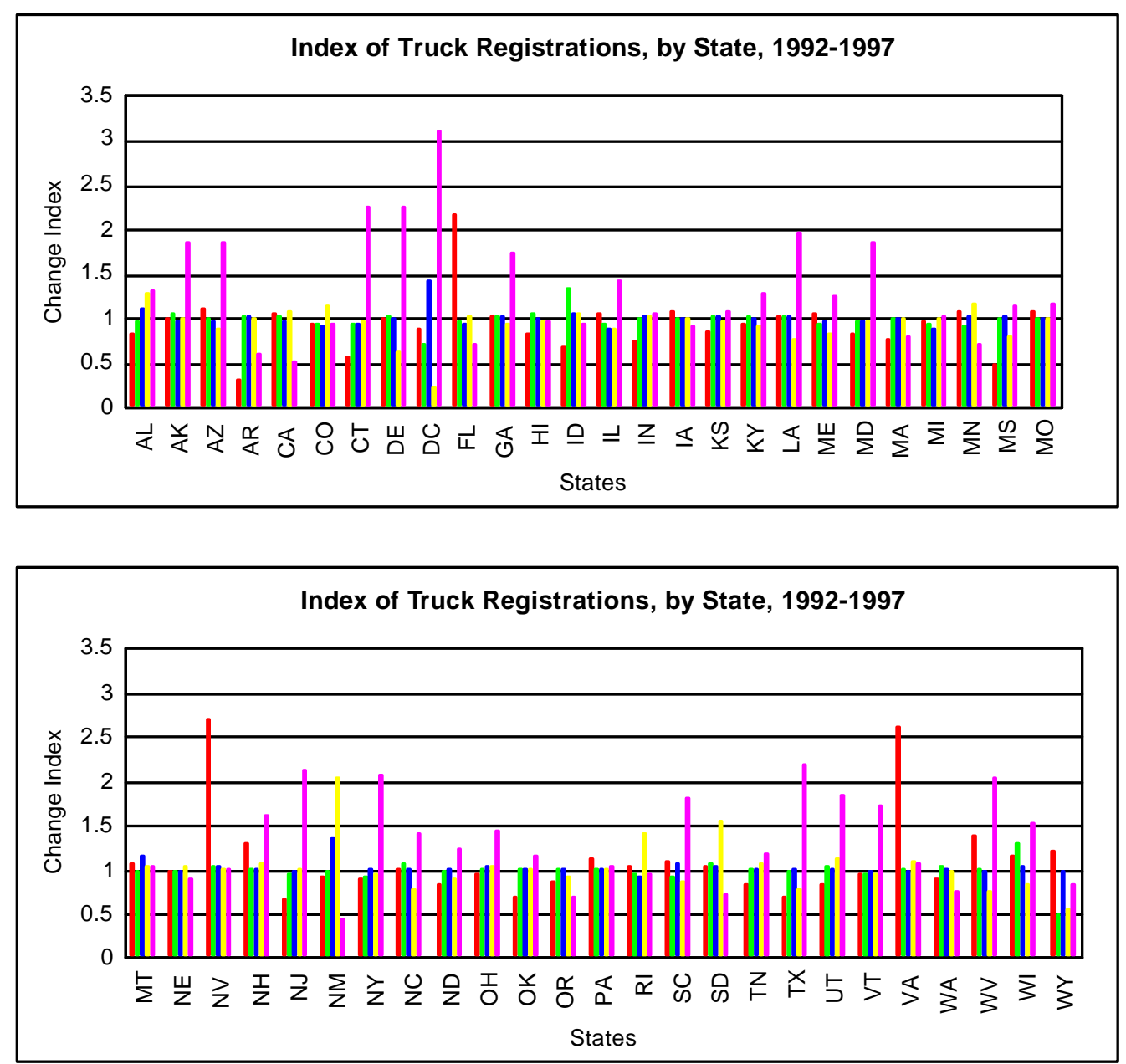

Figure 2. Change index of truck registrations, by State, for the years 1992-1997. The change index, which is computed by dividing the current year's value by the previous year's value, shows the unstable nature of the number of truck registrations factor. 
Additional information on the five factors in the formula in use in June 1997, when the Workgroup first convened, is provided in Appendix B, Table B.1. In this table, ORNL summarized the strengths and weaknesses of each factor and provided analyses based on the stability index, correlation with the other factors (to ensure that factors were not redundant), and factor availability.

In addition to the five factors discussed above, the Workgroup discussed a large number of potential new formula factors. These factors were identified in an attempt to better quantify the level of motor carrier activity within any given State. ORNL provided guidelines on determining when a factor was appropriate for MCSAP purposes (Figure 3).

HOW TO JUDGE A “GOOD” FACTOR
- A good FACTOR will be related to crash exposure/potential; it
will be easily understood; its data source will be respected,
reliable over time, complete, and accurate.
- If any FACTOR is closely correlated with another factor, then
this correlation must be considered in order to avoid
redundant factors. If both factors are considered valid and
useful, though correlated, then a weighting scheme should be
considered to adjust for the correlation.
- For the purposes of maintaining a stable allocation of MCSAP
funds, the data values should be stable over time.

Figure 3. Desirable features of a factor being considered for use in the MCSAP formula.

Potential factors were examined in greater or lesser detail based on the advice and recommendation of ORNL and the decision and concurrence of the Workgroup. The potential formula factors listed below were considered and rejected for the reasons provided.

- Cost of Living. Proposed funding increases need to be driven by program requirements rather than the general economy.

- Intelligent Transportation System (ITS) activities. Other funding sources are available to develop and promote ITS technologies, and MCSAP funds can be better applied to areas that are more oriented to safety enforcement.

- Intermodal Activities. There is no reliable data source available at the current time.

- Number of Commercial Motor Vehicle Crashes. The Motor Carrier Management Information System (MCMIS) crash file is not ready yet for rigorous use as a factor for appropriation of funding. However, once MCMIS becomes more mature, this is a potential future source of data.

- Number of Commercial Buses. There is no reliable source of data at this time. 
- State Contribution/Effort. It is difficult to measure authoritatively all levels of State expenditure and in-kind costs.

- Land Area. Land area was also considered during the 1992 effort to reexamine the formula factors. It was not considered to be a fair factor because larger areas do not necessarily represent more motor carrier activity.

- Miles of Interstate Highways. Interstate miles is highly correlated with road miles, which is a well-understood, stable, existing factor.

- Miles of National Highway System (NHS). NHS miles is highly correlated with road miles, which is a well-understood, stable, existing factor. In addition, the Workgroup believed that the MCSAP program should be comprehensive - based on all road miles, not just the NHS.

If there was a valid source for the data and if the Workgroup members felt that the potential factor was worth further examination, ORNL analyzed the factor in much greater detail than was used for the factors in the previous list. In addition, analyses were conducted to determine the impact of the incorporation of various factors on individual States. Factors that were examined in greater detail are briefly described below. Additional information on these potential new factors, their data sources, and their analyses is provided in Table B.2 of Appendix B.

- Lane Miles. Lane miles is highly correlated with road miles, which is a well-understood existing factor.

- Traffic Density Index. Traffic density was defined in several ways - VMT/road miles, VMT/lane miles, and commercial VMT/lane miles. All three definitions were tested. The traffic density index had no correlation with population or special fuels, both of which were considered very good measures of heavy truck activity. Analyses suggested that the traffic density index at the State level does not accurately reflect the potential for crash involvement due to uncontrollable variables that affect crash occurrence. ${ }^{5}$

- Commercial Truck Vehicle Miles Traveled (CVMT). When derived using Highway Statistics data, this factor is not easy to compute and is highly correlated with the total VMT of all vehicles. Neither the International Registration Plan (IRP) nor the International Fuel Tax Agreement (IFTA) can be used as a source of data for CVMT because of a lack of conformity and consistency at the present time.

- Population Estimates. This factor is very stable, easy to obtain, and well-recognized as a valid measure. It was decided to use this factor in the formula.

- Three-year Moving Average of Population Estimates. This factor is more complicated to derive than using the annual population estimates and is very highly correlated with the annual estimates.

- Number of Commercial Carriers. The MCMIS carrier census file contains information on the number of interstate carriers but not on intrastate carriers; to derive the number

\footnotetext{
${ }^{5}$ For example, the State of Texas has several large cities, each of which has a very high traffic density index; however, because of its large expanses of essentially rural land, its overall traffic density index is relatively low, only about one-fifth of that of Washington, D.C.
} 
of intrastate carriers within a State based on MCMIS and other sources of data [e.g., the Truck Inventory and Use Survey (TIUS)] is an unstable process and difficult to replicate.

- Hazardous Materials Incidents and Hazardous Materials VMT. The current data sources do not contain intrastate carriers; in addition, the VMT for trucks carrying hazardous materials is not available on a State level.

- Number of Commercial Drivers' Licenses (CDL). The Commercial Driver's License Information System (CDLIS) currently does not purge records of inactive drivers and may be unreliable because data must be retrieved from individual State systems. Accurate and updated data collection would be costly. CDL data from the MCMIS Carrier Census File does not contain intrastate carriers.

\subsection{Formula Development}

After extensive analysis, the Workgroup proposed that the following factors should be included in the formula for determining the baseline allocation:

- road miles, because this factor can be a proxy for crash exposure, is easily understood, applies to all types of vehicles, is very stable over time, and is recognized by and can be replicated by the States;

- total VMT, for the same reasons;

- annual population estimates, because population is a factor which is recognized by the States and population reflects motor carrier activities - that is, more populated areas are more likely to be supported by greater motor carrier activity; the annual estimates are recommended because they have a high correlation with the decennial census and yet have the advantage of representing the most accurate population sizes each year; and

- special fuels consumption, because this factor reflects the level of motor carrier activity, is from an audited program for all States, and is based on actual fuel usage.

After determining the best factors to be used in the formula for allocation of basic funds, the Workgroup examined various weighting scenarios. Three scenarios were examined at length:

- Case 1: road miles (25\%), total VMT (25\%), and special fuel consumption (25\%), and annual population estimates (25\%);

- Case 2: road miles (30\%), total VMT (25\%), special fuel consumption (35\%), and annual population estimates $(10 \%)$;

- Case 3: road miles (33\%), total VMT (33\%), and special fuel consumption (33\%).

MCSAP allocations based on these weighting scenarios correlated highly with the crash rates as reported by the Fatality Analysis Reporting System (FARS) and, to about the same extent, with the MCMIS crash data. Case 1 was recommended because it allocated the greatest share of MCSAP funding to the States with the largest number of motor carrier crashes.

In order to avoid severe negative impacts to States because of allocation changes that fluctuate from one year to the next, the Workgroup proposed to apply a "hold harmless" 
condition to the allocation formula. The definition of hold harmless is that a State may receive more funding than it received in a previous year but that it will not receive less MCSAP funds than it received in a particular year. The Workgroup recommended that 1996 be the baseline year for the hold harmless condition. This year was picked because the total amount of funding was similar to what was expected in future funding, although future funding was expected to grow. (Actually, the funding has grown by such a large amount that application of a hold harmless condition is no longer deemed necessary.)

In order to achieve a balanced program and to ensure that every State is afforded the opportunity to participate in MCSAP, the basic apportionment formula was adjusted for maximum and minimum allocations. At the time of the first Workgroup meeting (June 1997), the ceiling amount was $4.944 \%$ of the total amount available for allocation, and the floor was $0.44 \%$ or $\$ 250,000$, whichever was higher.

The Workgroup recommended that the ceiling of $4.944 \%$ be maintained. The Workgroup also recommended that the allocation for the Territories be set at $\$ 250,000$, and the minimum allocation for the States and Puerto Rico be set at $\$ 350,000$ or $0.44 \%$ of available program funds, whichever was higher. The rationale for setting higher minimum allocations for the States and Puerto Rico than for the Territories was because the Territories have low statistics for population, road miles, and VMT (no statistics are provided for special fuels consumption) and because the Territories, during ISTEA, had not used all of their MCSAP monies.

Therefore, the Workgroup arrived at a baseline allocation formula based on the four equally weighted factors, computed using a hold harmless condition and considering maximum and minimum limits. It should be noted that, because MCSAP funding appropriations for TEA-21 were significantly higher than they were in 1996, the hold harmless condition was not written into the Final Rule. It should also be noted that the floor for the Territories was set at $\mathbf{\$ 3 5 0 , 0 0 0}$ in the Final Rule and that the floor for the States and Puerto Rico remained at $\$ 350,000$ or $0.44 \%$, whichever was higher.

\subsection{Scenario Comparisons}

Specific scenarios were analyzed to compare impacts on States and regions. Changing the factors or weights of the factors, altering floor and/or ceiling values, or applying conditions

such as hold harmless allowed the Workgroup members to immediately see the answers to "What if?" questions. ORNL provided guidelines (Figure 4) on how to use the scenario comparisons for judging a formula and related conditions. A sample scenario comparison with funding amounts blanked out is provided in Appendix C. 


\section{HOW TO JUDGE A “GOOD” SCENARIO}

- After selecting good FACTORS, weight them as appropriate, determine a ceiling and a floor; consider adding a "hold harmless" condition.

- After running the SCENARIO, consider impacts on the States and Territories. In a comparison with some standard (e.g., the 1996 State allocations), consider the following impacts:

1. What is the greatest loss?

2. What is the greatest gain?

3. How many States lose funds; what is the percentage of the loss?

4. How many States gain funds, what is the percentage of the gain?

Figure 4. Guidelines for comparisons of scenarios.

\subsection{Incorporation of Performance Incentives}

The MCSAP Formula Workgroup looked at two examples of performance-based formulas the Federal Pipeline Safety Grant Program and the U.S. Coast Guard performance-based case studies. Neither seemed usable in the MCSAP situation because those industries are so different from the motor carrier industry. The Workgroup approached the problem of incorporating performance in the allocation process by addressing four major tasks as listed below.

1. Determine how the MCSAP program's available monies should be divided between the basic MCSAP funds and performance-based MCSAP funds. Should funds for the basic formula be constant at a particular amount and the performance-based funds be allowed to grow according to the amount of the authorization? Should the entire amount authorized by Congress be allocated using a single formula that incorporated performance? Should funding for the two categories be kept separate and both allowed to grow?

2. Determine the philosophy for granting funds. Should the money be put where the problems are, or should States be rewarded for improved performance (e.g., reduced crashes)?

3. Identify appropriate factors to describe performance. How is "improved performance" defined? Can improvement be measured through a reduction in total CMV-involved crashes (or crash rates), reduction in CMV-involved fatalities (or fatality rates), identification and resolution of specific problems, implementation of innovative programs to solve particular issues, timeliness and accuracy of uploaded data elements, traffic enforcement activities, or roadside inspections? Some potential crash-related factors and their data sources are listed in Appendix D. 
4. Decide mathematically how to apply the performance factors. Should there be a formula for allocation? Can a system based on shares be designed? Can a "formula" be constructed to reward performance and still consider the differences between the large and small States in the scope of their motor carrier issues?

Prior to TEA-21, MCSAP had been a program that encouraged enforcement strategies and used an allocation formula designed to maintain existing programs and prevent year-to-year impacts on the States. Designing a "new" program to distribute funds that would be considered as incentives to increase motor carrier safety was problematic. MCSAP was, and always had been, a program with the purpose of encouraging motor carrier safety.

Although several solutions were proposed and ten different methodologies for applying the performance factors were discussed, there was no final consensus on a performance-based formula or plan for allocation at the end of the second Workgroup meeting.

During the months following the Workgroup meeting, ORNL and FHWA ran additional scenarios. Although the performance-based program in the MCSAP Final Rule is unlike any particular methodology proposed by the Workgroup, it includes many characteristics (e.g., maintaining a formula-based allocation for normal MCSAP program activities and increasing the incentive funding amounts gradually) of the Workgroup discussion of methodologies for allocation.

The four major issues considered by the Workgroup concerning allocation of performance funds were resolved in the MCSAP Final Rule as follows:

1. Determine how the MCSAP program's available monies should be divided between the basic MCSAP funds and performance-based MCSAP funds. The split between basic program funds and incentive funds was set at 95\% and 5\%, respectively, for FY2001. Because of the emphasis on performance improvements, the share going to incentive funds was increased annually; for example, in FY2003, the split was set at $89 \%$ for basic funds and $11 \%$ for incentive funds.

2. Determine the philosophy for granting funds. Generally speaking, the Workgroup concurred that a performance-based program must reward States that actually improve performance - that is, reduce crashes. It was also noted that there is a need to reward States that maintain exemplary performance. Therefore, performance-based funds should be used to reward both exemplary and improved performance.

3. Identify appropriate factors to describe performance. In the Final Rule, areas for judging improved performance were as follows:

- a reduction in the number of fatal accidents involving large trucks (5 shares),

- a reduction in the large-truck-involved fatal accident rate (4 shares) or maintenance of a rate that is among the lowest $10 \%$ of all MCSAP recipients ( 3 shares),

- CDL verification during all roadside inspections (2 shares),

- accurate and timely uploading of CMV inspection data (2 shares), and

- accurate and timely uploading of CMV accident reports (2 shares).

4. Decide mathematically how to apply the performance factors. According to the Final Rule, incentive funds were allocated by finding the total of all States' shares and 
dividing this number into the total amount of incentive funding available to calculate the value of each share. Each State's incentive allocation was then found by multiplying the State's number of shares times the value of one share times the State's participation rate in the basic program funds.

\subsection{Spreadsheet}

ORNL developed a spreadsheet to automate the MCSAP calculations. ORNL also extended the spreadsheet's capabilities in order to do "on the fly" analysis, showing the immediate impact of ideas like raising the "floor" amount or "holding harmless" to a certain level. This spreadsheet was used during the second Workgroup meeting and was helpful in evaluating the effects of different scenarios presented during the meeting.

ORNL also enhanced this spreadsheet to evaluate different methodologies for allocating the incentive funds (performance-based funding) distribution. When the Final Rule was issued, the spreadsheet was finalized to calculate the formula allocation of the basic program funds, as well as the allocation of incentive funds. Under TEA-21, the FHWA can annually update the data for each of the four factors used on this spreadsheet to determine each State's MCSAP allocation. (See Appendix E for spreadsheet programming details.)

\section{FEDERAL REGISTER (49 CFR 350) NOTICES}

ORNL was involved in the preparation of both the preliminary and final MCSAP announcements as published in the Federal Register.

\subsection{Notice of Proposed Rule Making (March 1999)}

For the NPRM, ORNL prepared sections on "The MCSAP Formula Workgroup," "Potential New Factors," and "Proposed Allocation Formula." ORNL also reviewed and commented on the entire draft text of the NPRM prior to publication.

The MCSAP NPRM was published in the Federal Register on March 9, 1999, and may be viewed at http://www.nara.gov/fedreg .

\subsection{Final Rule (March 2000)}

ORNL conducted the initial analysis of comments on the NPRM, organizing the comments into categories, responding to the comments within each category, and writing the text for the section titled "Specific Concerns" in the Final Rule. In addition, ORNL reviewed several versions of the Final Rule prior to its publication. The MCSAP Final Rule was published in the Federal Register on March 21, 2000, and may be viewed at http://www.nara.gov/fedreg . 
When comments were received on the NPRM, FHWA assigned a docket number to each letter and posted the letter on the Worldwide Web. Using this source for the comments, ORNL populated a summary table with the docket number, date the response was received, commenting organization, and a synopsis of key comments from each response. This synopsis, in the form of a bulleted list, was critical to later analysis of the comments. After the close of the comment period, ORNL extracted common themes (a letter might contain one or many themes) from the summary table and created another table. This table, which was ordered by theme, cross-referenced the docket numbers of responses expressing a concern related to each specific theme. This theme table provided a clear view of the major concerns as expressed by States, Territories, local agencies, associations, trucking companies, and one individual.

Using the summary table and the theme table, ORNL initiated the text responding to the comments, which appeared in the Final Rule. The most common comments on the NPRM and their resolutions are listed in Appendix F.

\section{BROCHURE}

A full-color, tri-fold brochure was designed by ORNL. The purpose of the brochure was both to advertise MCSAP opportunities to the States and to give the States a quick overview of how to obtain funds.

A file with the contents of the brochure is located on the web at http://wwwcta.ornl.gov/Research/sda/MCSAP-Brochure.pdf or at http://www.fmcsa.dot.gov/pdfs/MCSAPBrochure.pdf .

\section{SUMMARY}

From the initial workgroup meeting to publication of the Final Rule, the formula evaluation and rulemaking process took two years and nine months. Several major delays occurred, including an extension of ISTEA, lengthy Federal budget negotiations before TEA-21 was enacted, and a reorganization of the Federal Highway Administration, which resulted in the dissolution of the Office of Motor Carriers and the creation of the Federal Motor Carrier Safety Administration. In addition, there were changes in direction concerning the necessity for incorporating performance-based conditions within, or in addition to, the formula allocation of basic program funds.

The distribution formula for apportioning basic MCSAP funds, as described in the Final Rule (Fed. Regist., Vol. 65, No. 55, Tuesday, March 21, 2000), was essentially that recommended by the MCSAP Workgroup. The MCSAP Final Rule also included a method for distributing incentive funds based on improved performance. Although the Workgroup as a whole was not able to determine a preferred manner for distributing performance-based 
funds, ORNL continued to work with the MCSAP Program Office to determine the impacts of various methodologies for distribution of incentive funds.

\section{RECOMMENDATIONS}

At the time of the next formula evaluation, a total examination of factors, such as that conducted for this tasking, will not be necessary. Only new or improved data sources need to be re-addressed. (Unpublished documentation, as noted in the References listing, concerning the analyses of factors is available from the FMCSA.)

ORNL recommends that the MCMIS crash file definitely be considered as a data source for the next evaluation because, by that time, this file should be fully populated and a rich source of motor carrier information. The MCMIS crash file, which contains a census of all incidents involving trucks and buses that result in fatal, injury, or tow-away crashes, could be used in conjunction with FARS fatality data to present a total picture of the motor carrier crash problem.

In addition, if the MCMIS carrier census file has incorporated intrastate as well as interstate carriers, the MCMIS carrier census file, too, should be considered as a source of carrier information.

ORNL also recommends that the IRP be considered as a source for truck travel by State. The IRP may improve uniformity among States and ease of data acquisition by the time new formula factors are considered.

Finally, if the CDLIS becomes a more centralized, reliable system with regular updates, then use of CDL information by State should be reconsidered as a potential factor. 



\section{REFERENCES}

Oak Ridge National Laboratory. "Motor Carrier Safety Assistance Program," March 2000. [Brochure.] Available at http://www-cta.ornl.gov/Research/sda/MCSAPBrochure.pdf or at http://www.fmcsa.dot.gov/pdfs/MCSAPBrochure.pdf or contact Ms. Bonnie Simmons at Federal Motor Carrier Safety Administration, 202-3662967.

Oak Ridge National Laboratory. "Draft Discussion Notes: Analysis of Factors to be Used in the MCSAP Allocation Formula," October 1997. [Unpublished notes.]

Oak Ridge National Laboratory. "Draft Supplementary Information: Analysis of Factors to be Used in the MCSAP Allocation Formula," October 1997. [Unpublished notes.]

U.S. Census Bureau, Population Division. "State Population Estimates and Demographic Components of Population Change: 1990 to 1999," http://www.census.gov/population/estimates/state/st-99-2.txt .

U.S. Department of Transportation, Federal Highway Administration. "Motor Carrier Safety Assistance Program,” Docket Nos. MC-91-7, MC-91-15, MC-92-17, Notice of Proposed Rulemaking (NPRM), Fed. Regist., Vol. 57, No. 74, Thursday, April 16, 1992, pp. 13572-13590.

U.S. Department of Transportation, Federal Highway Administration. "Motor Carrier Safety Assistance Program,” Docket Nos. MC-91-7, MC-91-15, MC-92-17, Final Rule, Fed. Regist., Vol. 57, No. 174, Tuesday, September 8, 1992, pp. 40946-40964.

U.S. Department of Transportation, Federal Motor Carrier Safety Administration. "Motor Carrier Safety Assistance Program (MCSAP)," Docket No. FHWA-98-4878, Notice of Proposed Rulemaking (NPRM); Request for Comments, Fed. Regist., Vol. 64, No. 45, Tuesday, March 9, 1999, pp. 11414-11431. Also available at http://www.nara.gov/fedreg .

U.S. Department of Transportation, Federal Motor Carrier Safety Administration. "Motor Carrier Safety Assistance Program,” Docket No. FMCSA-98-4878, Final Rule, Fed. Regist., Vol. 65, No. 55, Tuesday, March 21, 2000, pp. 15092-15110. Also available at http://www.nara.gov/fedreg .

U.S. Department of Transportation, Federal Highway Administration. Highway Statistics, annual updates. Available at http://www.fhwa.dot.gov/ohim/ohimstat.htm . 


\section{APPENDIX A}

\section{MCSAP FORMULA WORKGROUP PARTICIPANTS}

Ms. Jane Nadeau

State Programs Specialist, Massachusetts

Office of Motor Carriers, Region 1

Federal Highway Administration

Mr. Randy Sechrist

State Programs Specialist, Maryland

Office of Motor Carriers, Region 3

Federal Highway Administration

Mr. Don G. Taylor

State Programs Manager

Office of Motor Carriers, Region 4

Federal Highway Administration

Mr. Darin Jones

State Programs Manager

Office of Motor Carriers, Region 5

Federal Highway Administration

Mark Westmoreland

State Director, Arkansas

Office of Motor Carriers, Region 6

Federal Highway Administration

Mr. Kent D. Fleming

State Director, Iowa

Office of Motor Carriers, Region 7

Federal Highway Administration

Mr. Robert Kelleher

State Director, Utah

Office of Motor Carriers, Region 8

Federal Highway Administration

Ms. Susan Seckler

State Programs Manager

Office of Motor Carriers, Region 9

Federal Highway Administration

\author{
Mr. Andy Eno \\ State Director, Oregon \\ Office of Motor Carriers, Region 10 \\ Federal Highway Administration
}

Ms. Bonnie Simmons

State Programs Division, HSA30

Headquarters, Office of Motor Carriers

Federal Highway Administration

Ms. Barbara Kenefake

State Programs Division, HSA30

Headquarters, Office of Motor Carriers

Federal Highway Administration

Mr. Robert Proferes

Policy, Planning \& Customer Liaison Division, HPS-10

Headquarters, Office of Motor Carriers

Federal Highway Administration

Mr. Dale Sienicki

Analysis Division, HIA-20

Office of Motor Carriers

Federal Highway Administration

Linda Taylor

State Programs Division, HSA-30

Headquarters, Office of Motor Carriers

Federal Highway Administration

Ms. Patricia Hu

Oak Ridge National Laboratory

Ms. Tykey Truett

Oak Ridge National Laboratory

Ms. Stacy Davis

Oak Ridge National Laboratory 


\section{APPENDIX B}

\section{FACTORS OVERVIEW}

Table B. 1 contains the highlights of an analysis of the formula factors that were being used in the formula at the initiation of the Workgroup (June 1997). An analysis of proposed new formula factors is provided in Table B.2 for those factors that were considered worthy of an extended analysis. 


\begin{tabular}{|c|c|c|c|c|c|}
\hline \multicolumn{6}{|c|}{ Table B.1. Evaluation of Current Motor Carrier Safety Assistance Program (MCSAP) Formula Factors } \\
\hline Factor & Strengths & Weaknesses & Availability & $\begin{array}{l}\text { Correlation with other } \\
\text { factors }\end{array}$ & Stability index \\
\hline $\begin{array}{l}\text { Road miles, all } \\
\text { highways }\end{array}$ & $\begin{array}{l}* \text { Provides an indirect measure of } \\
\text { crash exposure } \\
* \text { Is easily understood } \\
* \text { Applies to all types of vehicles } \\
* \text { Source of data is respected by } \\
\text { states }\end{array}$ & $\begin{array}{l}\text { * Includes road miles not fr equently } \\
\text { used by commercial trucks } \\
* \text { Does not, in itself, relate directly to } \\
\text { Motor Carrier safety }\end{array}$ & $\begin{array}{l}\text { Highway } \\
\text { Statistics; } \\
\text { Annual }\end{array}$ & $\begin{array}{l}\text { Corr. coefficients: } \\
\text { special fuels, } 0.82827 ; \\
\text { AVMT, } 0.73304 ; \\
\text { population, } 0.68854 ; \\
\text { registrations, } 0.58478\end{array}$ & $\begin{array}{l}\text { Very stable (index } \\
\text { consistently between } \\
0.8 \text { and } 1.2 \text {, except for } \\
\text { AZ) }\end{array}$ \\
\hline $\begin{array}{l}\text { Vehicle miles } \\
\text { traveled } \\
\text { (AVMT), all } \\
\text { vehicles }\end{array}$ & $\begin{array}{l}\text { * Provides a measure of crash } \\
\text { exposure potential } \\
\text { * Applies to all types of vehicles } \\
\text { * Is easily understood }\end{array}$ & $\begin{array}{l}\text { * Since sampling and estimation are } \\
\text { used to compute VMT, it might be } \\
\text { subject to errors }\end{array}$ & $\begin{array}{l}\text { Highway } \\
\text { Statistics; } \\
\text { Annual }\end{array}$ & $\begin{array}{l}\text { Corr. coefficients: } \\
\text { population, } 0.98578 ; \\
\text { special fuels, } 0.94750 ; \\
\text { registrations, } 0.86888 \\
\text { road miles, } 0.73304\end{array}$ & $\begin{array}{l}\text { Stable (index ranges } \\
\text { between } 0.9 \text { and } 1.5 \text { ) }\end{array}$ \\
\hline Population & $\begin{array}{l}* \text { Provides an indirect me asure of } \\
\text { the crash exposure } \\
* \text { Is easily understood }\end{array}$ & $\begin{array}{l}\text { * When the decennial census is used, } \\
\text { the } 10 \text {-year update could have a } \\
\text { significant impact on some states }\end{array}$ & $\begin{array}{l}\text { Census Bureau; } \\
\text { Once each ten } \\
\text { years }\end{array}$ & $\begin{array}{l}\text { Corr. coefficients: } \\
\text { AVMT, 0.98578; } \\
\text { special fuels, } 0.91335 ; \\
\text { registrations, } 0.85011 ; \\
\text { road miles, } 0.68854\end{array}$ & $\begin{array}{l}\text { No changes year to } \\
\text { year; possible large } \\
\text { change every } 10 \text { years } \\
\text { (with new decennial } \\
\text { census results) }\end{array}$ \\
\hline $\begin{array}{l}\text { Special fuels } \\
\text { consumption }\end{array}$ & $\begin{array}{l}* \text { Reflects the level of motor } \\
\text { carrier activity (measures diesel } \\
\text { and LPG sales) } \\
* \text { Is from an audited program for } \\
\text { all states } \\
* \text { Is based on actual fuel usage }\end{array}$ & $\begin{array}{l}\text { * Picks up some vehicles in the } 10,000 \text { - } \\
26,000 \text { pound category which are not } \\
\text { commercial } \\
\text { * Loses commercial vehicles that use } \\
\text { gasoline }\end{array}$ & $\begin{array}{l}\text { Highway } \\
\text { Statistics; } \\
\text { Annual }\end{array}$ & $\begin{array}{l}\text { Corr. coefficients: } \\
\text { AVMT, } 0.94750 ; \\
\text { population, } 0.91335 ; \\
\text { road miles, } 0.82827 ; \\
\text { registrations, } 0.77047\end{array}$ & $\begin{array}{l}\text { Quite a lot of variation } \\
\text { for certain states } \\
\text { (index ranges of } 0.3 \text { to } \\
2.3 \text { for } \mathrm{AK} \text { ) }\end{array}$ \\
\hline $\begin{array}{l}\text { Heavy truck } \\
\text { registrations }\end{array}$ & $\begin{array}{l}* \text { Has a commercial vehicle } \\
\text { flavor (registrations of heavy } \\
\text { trucks) }\end{array}$ & $\begin{array}{l}* \text { May be weighted in favor of states } \\
\text { with low registration fees } \\
* \text { Does not measure where trucks are } \\
\text { actually being used }\end{array}$ & $\begin{array}{l}\text { Highway } \\
\text { Statistics; } \\
\text { Annual }\end{array}$ & $\begin{array}{l}\text { Corr. coefficients: } \\
\text { AVMT, } 0.86888 ; \\
\text { population, } 0.85011 ; \\
\text { special fuels, } 0.77047 \\
\text { road miles, } 0.58478\end{array}$ & $\begin{array}{l}\text { Unstable (index } \\
\text { ranges from } 0.4 \text { to } 3.1 \text { ) } \\
\text { and varies among all } \\
\text { states almost every } \\
\text { year }\end{array}$ \\
\hline
\end{tabular}

Notes on terminology:

- Availability: What is the source of the data; how frequently is it updated. It should be noted that annual updates are sufficient.

- $\quad$ Correlation with other factors: correlation coefficients of each of the current factors with the other factors were calculated to determine if there were redundant factors.

The p-value for each of these correlations is at 0.0001 .

- Stability: An index was calculated based on [(curr ent year)/(previous year)] for data from the 1993-97 spreadsheets and was graphed to determine variation. 
Table B.2. Evaluation of Potential Motor Carrier Safety Assistance Program (MCSAP) Formula Factors

\begin{tabular}{|c|c|c|c|c|c|}
\hline Factor & Strengths & Weaknesses & Availability & Correlation with related factors & Stability index \\
\hline Lane miles & $\begin{array}{l}* \text { Provides a measure of } \\
\text { crash exposure } \\
* \text { Applies to all types of } \\
\text { vehicles } \\
* \text { Simple to understand }\end{array}$ & $\begin{array}{l}* \text { As with road miles, } \\
\text { value is estimated } \\
\text { using sampling }\end{array}$ & $\begin{array}{l}\text { Highway } \\
\text { Statistics; } \\
\text { Annual }\end{array}$ & $\begin{array}{l}* \text { High correlation between lane miles } \\
\text { and road miles }(\text { correlation coefficient }= \\
0.99929, \mathrm{p}=0.0001)\end{array}$ & $\begin{array}{l}* \text { Did not conduct analysis } \\
\text { because the correlation } \\
\text { between lane miles and } \\
\text { road miles is close and road } \\
\text { miles is a very stable factor }\end{array}$ \\
\hline $\begin{array}{l}\text { Traffic density in dex } \\
\text { (AVMT/road miles) } \\
\text { Modified traffic } \\
\text { density index } \\
\text { (CVMT/lane miles) }\end{array}$ & $\begin{array}{l}* \text { Shows the potential for } \\
\text { crashes since it measures } \\
\text { traffic density } \\
* \text { Medium difficulty to } \\
\text { understand }\end{array}$ & $\begin{array}{l}* \text { Includes road miles } \\
\text { not frequently used by } \\
\text { commercial traffic } \\
* \text { VMT is estimated } \\
\text { using sampling }\end{array}$ & $\begin{array}{l}\text { Highway } \\
\text { Statistics; } \\
\text { Annual }\end{array}$ & $\begin{array}{l}* \text { No correlation with population } \\
(\text { correlation coefficient }=0.32280, \mathrm{p}= \\
0.0152) \\
* \text { No correlation with special fuel usage } \\
(\text { correlation coefficient }=0.18361, \mathrm{p}= \\
0.1755) \\
* \text { No correlation with heavy truck } \\
\text { registrations (correlation coefficient }= \\
0.19541, \mathrm{p}=0.1489)\end{array}$ & $\begin{array}{l}\text { * Fairly stable index } \\
\text { (between } 0.8 \text { and } 1.5, \\
\text { except for } \mathrm{AZ} \text { ) }\end{array}$ \\
\hline $\begin{array}{l}\text { CVMT, } \\
\text { Methodology \#1 } \\
\text { (combination trucks } \\
\text { only) }\end{array}$ & $\begin{array}{l}\text { * Methodology is easy to } \\
\text { understand and to compute } \\
* \text { Is directly related to motor } \\
\text { carrier activity }\end{array}$ & & $\begin{array}{l}\text { Highway } \\
\text { Statistics; } \\
\text { Annual }\end{array}$ & $\begin{array}{l}* \text { Highly correlated with other CVMT } \\
\text { methodologies }\end{array}$ & $\begin{array}{l}* \text { See analysis for } \\
\text { Methodology \#2 }\end{array}$ \\
\hline $\begin{array}{l}\text { CVMT, } \\
\text { Methodology \#2 } \\
\text { (combination and } \\
\text { single-unit trucks) }\end{array}$ & $\begin{array}{l}* \text { Methodology is easy to } \\
\text { understand and to compute } \\
* \text { Is directly related to motor } \\
\text { carrier activity }\end{array}$ & & $\begin{array}{l}\text { Highway } \\
\text { Statistics; } \\
\text { Annual }\end{array}$ & $\begin{array}{l}* \text { Highly correlated with other CVMT } \\
\text { methodologies } \\
* \text { Highly correlated with AVMT } \\
\text { (correlation coefficient }=0.94329, \mathrm{p}= \\
0.0001 \text { ) }\end{array}$ & $\begin{array}{l}\text { * Except for Oklahoma (no } \\
\text { mileage data supplied), } \\
\text { index is between } 0.5 \text { and } \\
2.2\end{array}$ \\
\hline $\begin{array}{l}\text { CVMT, } \\
\text { Methodology \#3 } \\
\text { (combination and a } \\
\text { percentage of single- } \\
\text { unit trucks) }\end{array}$ & $\begin{array}{l}* \text { Most accurate measure of } \\
\text { CVMT } \\
* \text { Is directly related to motor } \\
\text { carrier activity }\end{array}$ & $\begin{array}{l}\text { * Methodology is } \\
\text { difficult to understand } \\
\text { and difficult to } \\
\text { compute }\end{array}$ & $\begin{array}{l}\text { Highway Statis- } \\
\text { tics; Annual } \\
1992 \text { TIUS; } \\
\text { every five years }\end{array}$ & $\begin{array}{l}* \text { Highly correlated with other CVMT } \\
\text { methodologies }\end{array}$ & $\begin{array}{l}* \text { See analysis for } \\
\text { Methodology \#2 }\end{array}$ \\
\hline $\begin{array}{l}\text { Annual population } \\
\text { estimates }\end{array}$ & $\begin{array}{l}\text { * Updates population values } \\
\text { gradually rather than once } \\
\text { every } 10 \text { years }\end{array}$ & $\begin{array}{l}* \text { Is based on an } \\
\text { estimate }\end{array}$ & $\begin{array}{l}\text { Census Bureau; } \\
\text { Annual updates }\end{array}$ & $\begin{array}{l}* \text { High correlation with decennial census } \\
\text { (correlation coefficient }=1.00000) \\
* \text { High correlation with } 3 \text {-year moving } \\
\text { average of population estimates } \\
\text { (correlation coefficient }=1.00000 \text { ) }\end{array}$ & $*$ Very stable \\
\hline
\end{tabular}




\begin{tabular}{|c|c|c|c|c|c|}
\hline \multicolumn{6}{|c|}{ Table B.2. Evaluation of Potential Motor Carrier Safety Assistance Program (MCSAP) Formula Factors } \\
\hline Factor & Strengths & Weaknesses & Availability & Correlation with related factors & Stability index \\
\hline $\begin{array}{l}\text { Three-year moving } \\
\text { average of population } \\
\text { estimates }\end{array}$ & $\begin{array}{l}* \text { Updates population values } \\
\text { gradually rather than once in } \\
10 \text { years }\end{array}$ & $\begin{array}{l}* \text { Is based on an } \\
\text { estimate } \\
* \text { Is of medium } \\
\text { difficulty to } \\
\text { understand }\end{array}$ & $\begin{array}{l}\text { Census Bureau; } \\
\text { Annual updates }\end{array}$ & $\begin{array}{l}* \text { High correlation with decennial census } \\
\text { (correlation coefficient }=1.00000) \\
* \text { High correlation with annual } \\
\text { population estimates (correlation } \\
\text { coefficient }=1.00000)\end{array}$ & * Very stable \\
\hline $\begin{array}{l}\text { Number of power } \\
\text { units (trucks and } \\
\text { buses) }\end{array}$ & $\begin{array}{l}* \text { Is a measure of motor } \\
\text { carrier activity; is the only } \\
\text { measure of motor carrier } \\
\text { activity that includes buses }\end{array}$ & $\begin{array}{l}* \text { Does not include } \\
\text { intrastate carriers } \\
\text { except for those } \\
\text { transporting hazmat }\end{array}$ & $\begin{array}{l}\text { MCMIS Carrier } \\
\text { Census File; } \\
\text { Constantly } \\
\text { being updated }\end{array}$ & $\begin{array}{l}* \text { With } \mathrm{p}=0.0001 \text {, correlated with other } \\
\text { factors as follows: } \\
\text { special fuel, } 0.85836 \\
\text { CVMT, } 82422 \\
\text { AVMT, } 0.77519 \\
\text { truck registrations, } 0.57652\end{array}$ & $\begin{array}{l}\text { * No analysis conducted } \\
\text { for this factor because we } \\
\text { received only one data set; } \\
\text { the data is being constantly } \\
\text { updated with carrier } \\
\text { information }\end{array}$ \\
\hline Number of trucks & $\begin{array}{l}* \text { Is a measure of motor } \\
\text { carrier activity }\end{array}$ & $\begin{array}{l}* \text { Does not include } \\
\text { intrastate carriers } \\
\text { except for those } \\
\text { transporting hazmat }\end{array}$ & $\begin{array}{l}\text { MCMIS Carrier } \\
\text { Census File; } \\
\text { Constantly } \\
\text { being updated }\end{array}$ & $\begin{array}{l}\text { * Current }(1997) \text { data is correlated with } \\
1994 \text { heavy truck registration data } \\
\text { (correlation coefficient }=0.84640, p= \\
0.0001 \text { ) }\end{array}$ & $\begin{array}{l}* \text { No analysis conducted } \\
\text { for this factor because we } \\
\text { received only one data set; } \\
\text { the data is being constantly } \\
\text { updated with carrier } \\
\text { information }\end{array}$ \\
\hline $\begin{array}{l}\text { Hazardous material } \\
\text { incidents }\end{array}$ & $\begin{array}{l}\text { * Is a measure of hazardous } \\
\text { materials accidents }\end{array}$ & $\begin{array}{l}\text { * Data source does not } \\
\text { cover intrastate } \\
\text { carriers at this time } \\
\text { * Factor would be the } \\
\text { number of truck } \\
\text { crashes involving } \\
\text { hazmat; the database } \\
\text { does not include total } \\
\text { miles traveled with } \\
\text { hazmat; therefore, it } \\
\text { could be misleading }\end{array}$ & $\begin{array}{l}\text { DOT/ Research } \\
\text { and Special } \\
\text { Programs } \\
\text { Administration } \\
\text { (RSPA); } \\
\text { Annual }\end{array}$ & $\begin{array}{l}\text { * No analysis conducted for this factor } \\
\text { because we did not actually obtain any } \\
\text { data sets }\end{array}$ & $\begin{array}{l}* \text { No analysis conducted } \\
\text { for this factor because we } \\
\text { did not actually obtain any } \\
\text { data sets }\end{array}$ \\
\hline $\begin{array}{l}\text { Hazardous material } \\
\text { VMT }\end{array}$ & $\begin{array}{l}* \text { Is a measure of hazardous } \\
\text { materials transportation }\end{array}$ & $\begin{array}{l}* \text { Data source } \\
\text { provides an estimate } \\
\text { of mileage covered by } \\
\text { trucks which might be } \\
\text { carrying hazmat } \\
* \text { Survey has } \\
\text { infrequent updates }\end{array}$ & $\begin{array}{l}\text { Truck Inventory } \\
\text { and Use Survey } \\
\text { (TIUS); } \\
\text { Every five years }\end{array}$ & $\begin{array}{l}\text { * No analysis conducted for this factor } \\
\text { when we determined that it was not a } \\
\text { usable factor }\end{array}$ & $\begin{array}{l}* \text { No analysis conducted } \\
\text { for this factor when we } \\
\text { determined that it was not a } \\
\text { usable factor }\end{array}$ \\
\hline
\end{tabular}


Table B.2. Evaluation of Potential Motor Carrier Safety Assistance Program (MCSAP) Formula Factors

\begin{tabular}{|c|c|c|c|c|c|}
\hline Factor & Strengths & Weaknesses & Availability & Correlation with related factors & Stability index \\
\hline $\begin{array}{l}\text { CDL data from CDL } \\
\text { Information System }\end{array}$ & $\begin{array}{l}* \text { Is a measure of motor } \\
\text { carrier activity }\end{array}$ & $\begin{array}{l}\text { * Database is not } \\
\text { updated when licenses } \\
\text { are revolked or drivers } \\
\text { die } \\
* \text { Database was not } \\
\text { designed for the } \\
\text { purpose of obtaining } \\
\text { data for MCSAP } \\
\text { allocation } \\
* \text { Data may be } \\
\text { unreliable because } \\
\text { information must be } \\
\text { retrieved from } \\
\text { individual State } \\
\text { systems and then } \\
\text { manually combined } \\
\text { and recalculated }\end{array}$ & $\begin{array}{l}\text { CDL } \\
\text { Information } \\
\text { System (via a } \\
\text { pointer to each } \\
\text { state data } \\
\text { files); } \\
\text { Annual }\end{array}$ & $\begin{array}{l}* \text { With } \mathrm{p}=0.0001 \text {, correlated to other } \\
\text { factors as follows: } \\
\text { truck registrations, } 0.94646 \text { ) } \\
\text { special fuels, } 0.94946 \\
\text { MCMIS CDL data, } 0.84356 \text { ( note: } \\
\text { MCMIS CDL data does not include } \\
\text { intrastate carriers, except for those } \\
\text { transporting hazmat) }\end{array}$ & $\begin{array}{l}* \text { No analysis conducted } \\
\text { for this factor since only } \\
\text { two data sets (one of which } \\
\text { had data quality problems) } \\
\text { were obtained }\end{array}$ \\
\hline $\begin{array}{l}\text { CDL data from } \\
\text { MCMIS Carrier } \\
\text { Census File }\end{array}$ & $\begin{array}{l}* \text { Is a measure of motor } \\
\text { carrier activity }\end{array}$ & $\begin{array}{l}\text { * Does not include } \\
\text { intrastate carriers } \\
\text { except for those } \\
\text { transporting hazmat }\end{array}$ & $\begin{array}{l}\text { MCMIS Carrier } \\
\text { Census File; } \\
\text { Constantly } \\
\text { being updated }\end{array}$ & $\begin{array}{l}* \text { Correlated to the CDLIS data } \\
\text { (correlation coefficient }=0.84356, p= \\
0.0001)\end{array}$ & $\begin{array}{l}* \text { No analysis conducted } \\
\text { for this factor because only } \\
\text { one data set was obtained } \\
\text { and the MCMIS data file is } \\
\text { being constantly updated }\end{array}$ \\
\hline
\end{tabular}

\section{Notes on terminology:}

C Availability: What is the source of the data; how frequently is it updated. It should be noted that annual updates are sufficient.

C Correlation with other factors: correlation coefficients of the potential factor were compared with a factor in the current formula or with some other potential factor. The correlation plots were calculated using percentages, by state, for the factor. The $\mathrm{p}$-value for each correlation was 0.0001 unless otherwise stated.

C Stability: An index was calculated based on [(current year)/(previous year)] for data on the 1993 -1997 spreadsheets; the index was graphed to determine variation.

C Scenario: A comparison of total allocation dollars (when the pr oposed factor is incorporated within the formula) to total allocation dollars (using the original 1996 spreadsheet) using the same ceiling and floor. 


\section{APPENDIX C}

\section{EXAMPLE OF SCENARIO ANALYSIS}

This scenario was based on using fou $\mathrm{r}$ factors from the spreadsheet formula that existed at the time the Workgroup was formed in 1997. These four factors included road miles, all vehicle miles traveled, special fuels, and heavy truck registrations. Funding allocations based on this new scenario were compared with the funding allocations based on the original five -factor scenario. 


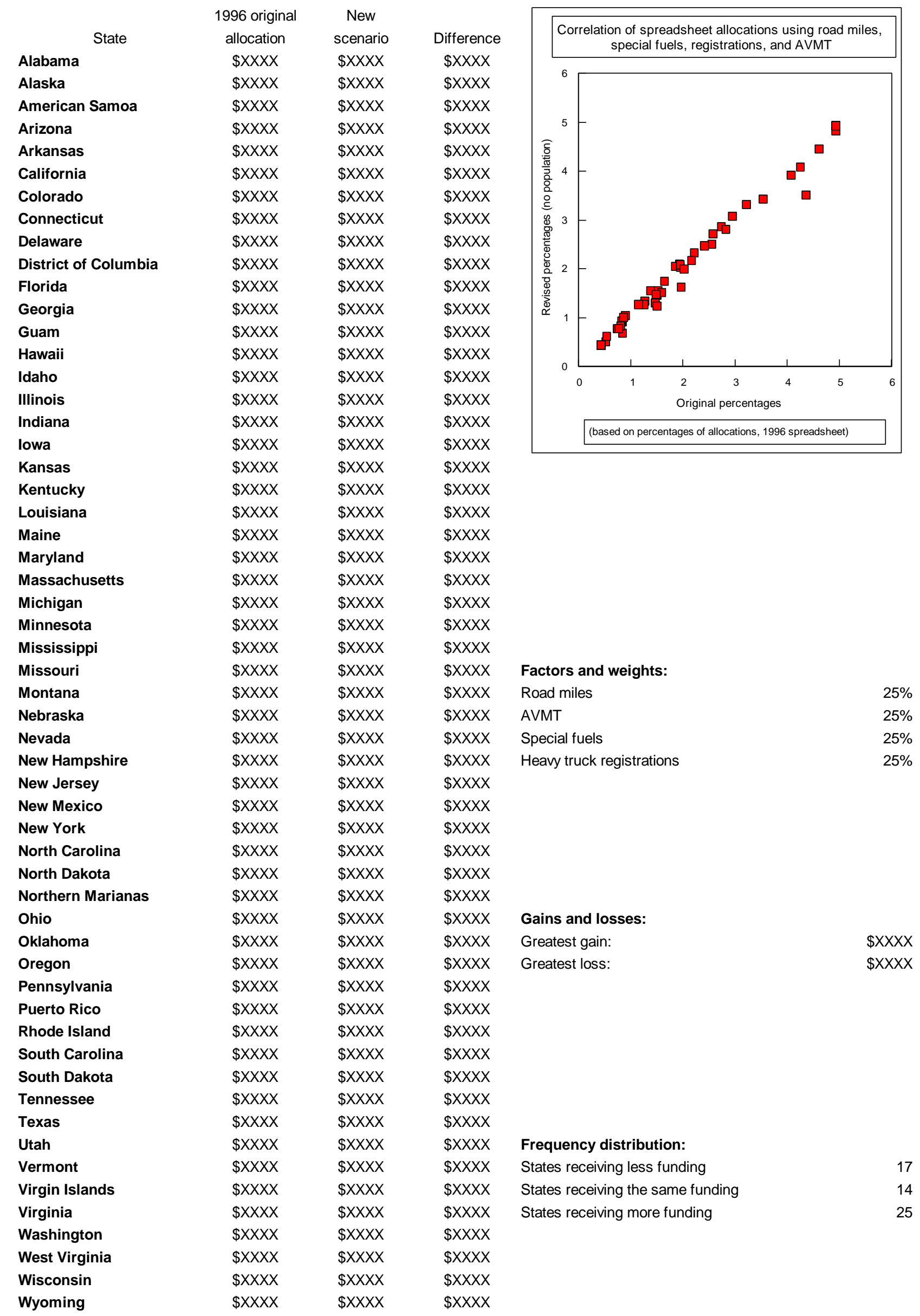




\section{APPENDIX D}

\section{CRASH-RELATED DATA FOR POTENTIAL USE AS PERFORMANCE-BASED "FACTORS"}

The information in this chart was correct as of the date of the second Wo rkgroup meeting, February 1998. Since that time, some descriptions (e.g., ownership of the data source; maturity of the data sets) may have changed. For definitions of the acronyms used in this table, please see the Acronyms and Initialisms list in the fro nt of this document.

From factors such as "number of fatal crashes," other factors describing rates could be derived (e.g., "fatal crashes/population"; "fatal crashes/VMT").

\begin{tabular}{|c|c|c|c|}
\hline Factor & Source & Strengths & Weaknesses \\
\hline $\begin{array}{l}\text { Number of fatal } \\
\text { crashes involving } \\
\text { large trucks; } \\
\text { number of large } \\
\text { trucks involved in } \\
\text { fatal accidents; } \\
\text { number of fatalities } \\
\text { in crashes involving } \\
\text { large trucks }\end{array}$ & MCMIS & $\begin{array}{l}\text { Is a mature, well- } \\
\text { documented, and trusted } \\
\text { source; data is considered } \\
\text { to be accurate, complete, } \\
\text { and timely } \\
\text { Is managed by FHWA } \\
\text { Office of Motor Carriers; } \\
\text { therefore, data is available } \\
\text { as needed in desired format }\end{array}$ & $\begin{array}{l}\text { Contains only information on } \\
\text { crashes involving fatalities } \\
\text { Data set is not considered (yet) to } \\
\text { be mature }\end{array}$ \\
\hline $\begin{array}{l}\text { Number of fatal } \\
\text { crashes for ALL } \\
\text { vehicles }\end{array}$ & FARS & $\begin{array}{l}\text { See above; involves all } \\
\text { vehicles, not just large } \\
\text { trucks }\end{array}$ & $\begin{array}{l}\text { Contains only information on } \\
\text { crashes involving fatalities }\end{array}$ \\
\hline $\begin{array}{l}\text { Total crashes } \\
\text { involving large } \\
\text { trucks (fatalities, } \\
\text { injuries, tow- } \\
\text { aways) }\end{array}$ & MCMIS & $\begin{array}{l}\text { Measures ALL crashes } \\
\text { involving large trucks, not } \\
\text { just those involving } \\
\text { fatalities; th erefore, is a } \\
\text { measure of total motor } \\
\text { carrier safety }\end{array}$ & $\begin{array}{l}\text { Data set is not considered (yet) to } \\
\text { be mature } \\
\text { Contains only information on } \\
\text { crashes involving motor carrier } \\
\text { vehicles }\end{array}$ \\
\hline $\begin{array}{l}\text { Total crashes } \\
\text { involving all } \\
\text { vehicles }\end{array}$ & $\begin{array}{l}\text { No source } \\
\text { now: potential } \\
\text { exists with } \\
\text { MUCC }\end{array}$ & & $\begin{array}{l}\text { Won't be available as a guideline } \\
\text { until mid }-98 \text {; date for } \\
\text { implementation by States will be } \\
\text { after that time }\end{array}$ \\
\hline $\begin{array}{l}\text { Comprehensive } \\
\text { elements (e.g., } \\
\text { traffic enforcement, } \\
\text { roadside } \\
\text { inspections, } \\
\text { compliance } \\
\text { reviews, uploading } \\
\text { of NGA data, OOS } \\
\text { verification, } \\
\text { educational } \\
\text { outreach) }\end{array}$ & $\begin{array}{l}\text { MCMIS (for } \\
\text { Safety Net } \\
\text { uploads) } \\
\text { Other sources } \\
\text { for other data } \\
\text { elements }\end{array}$ & & $\begin{array}{l}\text { Need to establish a precise criteria } \\
\text { for judging how well each State } \\
\text { meets each element } \\
\text { Need to establish a methodology } \\
\text { for scoring the combination of } \\
\text { elements } \\
\text { If the condition for meeting this } \\
\text { criteria is the same for all States, } \\
\text { this factor may overcompensate } \\
\text { smaller States }\end{array}$ \\
\hline
\end{tabular}




\section{APPENDIX E}

\section{SPREADSHEET}

The MCSAP basic program and incentive funds spreadsheet consists of eight individual sheets within one file. The purpose and inputs for each sheet are shown in Table E.1.

Table E.1. MCSAP Worksheets

\begin{tabular}{|c|c|c|}
\hline Worksheet title: & Purpose: & Input: \\
\hline Directory & $\begin{array}{l}\text { Contains information about the } \\
\text { spreadsheet organization and } \\
\text { inputs }\end{array}$ & None \\
\hline Allocation & $\begin{array}{l}\text { Contains programming for ba sic } \\
\text { fund allocation formula }\end{array}$ & $\begin{array}{l}\ddot{y} \text { Total basic program funds } \\
\ddot{Y} \text { Year }\end{array}$ \\
\hline Formula Inputs & $\begin{array}{l}\text { Contains data required for basic } \\
\text { fund allocation formula }\end{array}$ & $\begin{array}{l}\text { For the most current year available: } \\
\ddot{y} \text { VMT for all vehicles by State (Highway } \\
\text { Statistics, Table VM-2) } \\
\ddot{Y} \text { Special fuel use by State (Highway Statistics, } \\
\text { Table MF-21) } \\
\text { Population estimates by State (Census Bureau) } \\
€ \text { Half State designation }{ }^{1}\end{array}$ \\
\hline AVMT & $\begin{array}{l}\text { Contains historical VMT data for } \\
\text { crash rate calculation }\end{array}$ & $\begin{array}{l}\text { ÿ VMT for all vehicles by State (Highway } \\
\text { Statistics, Table VM-2) for the most current year } \\
\text { [Same as "Formula Inputs" sheet input] }\end{array}$ \\
\hline Crashes & $\begin{array}{l}\text { Contains historical crash data for } \\
\text { crash rate calculation }\end{array}$ & $\begin{array}{l}\ddot{y} \text { Fatal crashes involving a large truck by State } \\
\text { (FARS) for the most current year }\end{array}$ \\
\hline Rates & $\begin{array}{l}\text { Contains crash rate calculation } \\
\text { and comparison }\end{array}$ & $\begin{array}{l}\text { ஜ̈ Formulas must be updated to use correct } \\
\text { columns from AVMT and Crashes worksheets } \\
\text { [Instructions are given in the spreadsheet for } \\
\text { formula updates] }\end{array}$ \\
\hline Incentive & Contains incentive fund allocation & $\begin{array}{l}\text { ÿ Total incentive funds } \\
\ddot{Y} \text { State CDL check compliance } \\
\text { State upload of commercial motor vehicle } \\
\text { accident data timeliness } \\
€ \text { State upload of commercial motor vehicle } \\
\text { inspection data timeliness }\end{array}$ \\
\hline Total & $\begin{array}{l}\text { Contains final formula allocation } \\
\text { and incentive fund allocation for } \\
\text { each State }\end{array}$ & None \\
\hline
\end{tabular}

This series of worksheets can be updated each year to determine the amount of funding that the States will receive under the basic formula allocation and the incentive funds allocation. It will also be useful for case studies and impact analysis during the next formula evaluation.

\footnotetext{
${ }^{1}$ Half States receive half of their formula funding allocation due to incompatible Intrastate regulat ions.
} 


\section{APPENDIX F \\ MOST COMMON COMMENTS ON THE NOTICE OF PROPOSED RULEMAKING (NPRM)}

\begin{tabular}{|c|c|}
\hline Comment & Resolution \\
\hline $\begin{array}{l}\text { In the Basic Program Funds allocation } \\
\text { formula, drop the performance factor } \\
\text { adjustment, OR don't use crashes to } \\
\text { determine the performance factor } \\
\text { adjustment. }\end{array}$ & $\begin{array}{l}\text { The performance factor adjustment was not } \\
\text { written into the Basic Program Funds allocation } \\
\text { formula in the Final Rule. }\end{array}$ \\
\hline $\begin{array}{l}\text { Don't use crash rates to distribute the } \\
\text { Incentive Funds. }\end{array}$ & $\begin{array}{l}\text { Because rewarding States that lower their crash } \\
\text { rates is directly related to the MCSAP goal of } \\
\text { reducing crashes, crash rates remained in the Final } \\
\text { Rule for distributing Incentive Funds. }\end{array}$ \\
\hline $\begin{array}{l}\text { Don't use the percentages given in the } \\
\text { NPRM to split the Basic and the } \\
\text { Incentive Funds. }\end{array}$ & $\begin{array}{l}\text { The percentages for dividing MCSAP funds were } \\
\text { revised. }\end{array}$ \\
\hline $\begin{array}{l}\text { Give States with the biggest crash } \\
\text { problem (i.e., greatest number of crashes) } \\
\text { more money than States with smaller } \\
\text { crash problems. }\end{array}$ & $\begin{array}{l}\text { This methodology would provide no incentive for } \\
\text { accident reduction. Because the formula used to } \\
\text { distribute the Basic Program Funds provided the } \\
\text { greatest amount of funds to those States with the } \\
\text { greatest potential for accident problems, the } \\
\text { Incentive Fund was designed to reward improved } \\
\text { performance. }\end{array}$ \\
\hline $\begin{array}{l}\text { Don't use population in the calculation of } \\
\text { crash rate. }\end{array}$ & $\begin{array}{l}\text { In the Final Rule, vehicle miles traveled was used } \\
\text { instead of population in the calculation of the } \\
\text { crash rate in the Incentive Funds. }\end{array}$ \\
\hline $\begin{array}{l}\text { Use CMV crash rate instead of fatal crash } \\
\text { rate. }\end{array}$ & $\begin{array}{l}\text { The reason for not using CMV crash rate was the lack } \\
\text { of a mature, reliable data base as a source of the data. } \\
\text { Therefore, fatal crash rate remained in the Final Rule. }\end{array}$ \\
\hline $\begin{array}{l}\text { Don't use a ten-year average rate to } \\
\text { compare with the current one-year rate } \\
\text { for the crash rates in the Incentive Funds } \\
\text { distribution. }\end{array}$ & $\begin{array}{l}\text { To determine to the effectiveness of accident } \\
\text { reduction strategies in a year, the ten -year average } \\
\text { rate was compared to the one-year rate to } \\
\text { moderate the effect of yearly fluctuations in the } \\
\text { crash rate that might be caused by conditions } \\
\text { outside of a State's control (e.g., severe weather). } \\
\text { This methodology remained in the Final Rule. }\end{array}$ \\
\hline $\begin{array}{l}\text { Don't distribute Incentive Funds based on } \\
\text { timeliness of reporting data because it } \\
\text { will hurt the accuracy of the data. }\end{array}$ & $\begin{array}{l}\text { An accurate and timely accident database is } \\
\text { essential for an effective performance -based } \\
\text { program. Therefore, timely accident data uploads } \\
\text { remained in the Incentive Fund distribution. }\end{array}$ \\
\hline
\end{tabular}

For further information regarding NPRM comments, see the Federal Register, Volume 65, No. 55, Tuesday, March 21, 2000. 